\title{
ANALISIS DAYA SAING KOMODITAS MANGGIS DIKELOMPOK TANI WANAYASA, DESA BABAKAN, KECAMATAN WANAYASA, KABUPATEN PURWAKARTA, JAWA BARAT
}

\author{
RIZKA AULIA PUTRI*, DINI ROCHDIANI
}

Program Studi Agribisnis, Fakultas Pertanian, Universitas Padjajaran Jl. Raya Bandung Sumedang KM. 21, Hegarmanah, Jatinangor, Kabupaten Sumedang 45363 E-mail: rizkaauliaputri25@gmail.com

\begin{abstract}
Mangosteen is one of Indonesia's leading fruit commodities with high export demand and continues to increase, so that mangosteen becomes the largest contributor of Indonesian foreign exchange in the horticulture sector. The magnitude of the market potential provided by mangosteen commodities is not balanced by the sustained demand fulfillment in terms of both quantity and quality. The purpose of this study is to identify competitiveness through competitive advantage and comparative advantage as well as the impact of government policie. The research technique used is case study. This research was carried out in Wanayasa Farmer Group, in the Village of Babakan, Wanayasa District, Purwakarta Regency. Analyzed used Policy Analysis Matrix (PAM). The results showed that mangosteen in the village of Babakan has its competitiveness, either competitively $(P C R<1)$ or comparatively $(D C R<1)$, in which PCR values 0,92 and $D R C R$ 0,21. The impact of government policies om input-output have not been proven to be effective and to be less profitable for mangosteen farmers. It was showed by the value of EPC $<1$.
\end{abstract}

Keyword: Competitiveness, Mangosteen Commodities, Government Policy

\section{PENDAHULUAN}

Buah manggis merupakan salah satu komoditas buah dengan permintaan ekspor yang tinggi dan terus menerus meningkat, sehingga manggis menjadi penyumbang devisa terbesar Indonesia pada sektor hortikultura. Saat ini manggis menjadi primadona ekspor. Jumlah ekspor manggis $34,4 \%$ dari total ekspor buah dan $9,62 \%$ dari total produksi nasional (Kementerian Pertanian, 2015).

Jumlah ekspor manggis tahun 2013 mengalami penurunan yang sangat drastis yaitu 12.521 ton. Rata-rata kontribusi ekspor manggis terhadap produksi nasional pada tahun 2011-2015 adalah 13,48 persen dan sisanya 86,52 persen masih menjadi konsumsi lokal (Kementerian Pertanian, 2015). Menurut Kustiari, et al (2011), hal tersebut dapat menggambarkan bahwa produksi manggis Indonesia masih banyak yang belum memenuhi standar kualitas permintaan ekspor.

Jawa Barat merupakan produksi manggis terbesar di Indonesia dengan jumlah produksi tertinggi pada tahun 2015 adalah 69.314 ton. Salah satu penghasil manggis terbesar di Jawa Barat adalah Kabupaten Purwakarta (BPS, 2015). Kecamatan Wanayasa adalah kecamatan yang memiliki produksi dan produktivitas tertinggi di Kabupaten Purwakarta. Selain itu kualitas manggis yang dihasilkannya 
pun sangat baik. Jumlah tanaman di Kecamatan Wanayasa dari tahun 20132015 mengalami peningkatan (BPS, 2016). Walaupun tidak mengalami peningkatan yang signifikan, namun permasalahannya, peningkatan jumlah tanaman manggis tidak diikuti jumlah produksi untuk memenuhi permintaan ekspor.

Permintaan manggis selama ini adalah 20 persen dari total permintaan ekspor dari komoditi lainnya, akan tetapi $80 \%$ dari hasil produksi masih belum berkualitas ekspor, sehingga hal ini menyebabkan usahatani manggis sulit untuk berdaya saing dengan negara lainnya, seperti Cina, Malaysia, Thailand dan Australia (Kementerian Pertanian, 2015).

Teknologi budidaya dan pengolahan manggis yang masih tradisional, sehingga hal ini dapat menurunkan daya saing produk manggis di pasar dunia. Komoditas yang diekspor juga beberapa masi berupa manggis asalan yang mampu mengurangi nilai tambah industri manggis oleh negara yang dieskpor. Perhatian pemerintah juga masih sangat kurang terhadap pengembangan komoditas manggis (Muslim dan Nurasa, 2011).

Penelitian ini bertujuan untuk (i) Menghitung tingkat daya saing manggis di
Kecamatan Wanayasa, Kabupaten

Purwakarta, Jawa Barat, dan (ii) Mengetahui kebijakan pemerintah terhadap usahatani manggis di Kecamatan Wanayasa, Kabupaten Purwakarta, Jawa Barat.

\section{METODE PENELITIAN}

\section{Tempat dan Waktu Penelitian}

Penelitian dilakukan di Desa Babakan, Kecamatan Wanayasa. Pemilihan lokasi dilakukan secara sengaja (purposive) dengan mempertimbangkan bahwa daerah tersebut memiliki jumlah produksi manggis terbanyak di Kecamatan Wanayasa, Kabupaten Purwakarta. Penelitian ini diasumsikan bahwa umur ekonomis usahatani manggis di daerah penelitian adalah 25 tahun. Pengmpulan data penelitian dilakukan pada bulan Agustus-November 2017.

Teknik penelitian yang dilakukan adalah studi kasus yang dilakukan secara intensif, terperinci dan mendalam terhadap responden. Teknik penelitian studi kasus menggunakan seluruh populasi petani yang ada di Desa Babakan yang berjumlah 30 orang.

Data yang digunakan adalah data primer dan data sekunder. Data primer adalah data yang diperoleh secara langsung dari responden melalui hasil 
pengamatan dan wawancara dengan menggunakan daftar pertanyaan. Data sekunder diperoleh dari literatur-literatur yang relevan, hasil penelitian terdahulu yang terkait, Kementerian Pertanian, Dinas Pertanian, Badan Pusat Statistik, situs resmi dapartemen terkait serta instansi lainnya.

Untuk melihat daya saing manggis di Desa Babakan, Kecamatan Wanayasa sesuai dengan tujuan penelitian digunakan metode Matriks Analisis Kebijakan (Policy Analysis Matrix/PAM). Untuk menghitung daya saing diperlukan pengisian matriks analisis PAM yang terdiri atas beberapa komponen seperti yang tertera pada Tabel 1 .

Tabel 1. Policy Analysis Matrix

\begin{tabular}{|c|c|c|c|c|}
\hline \multirow[b]{2}{*}{$\begin{array}{l}\text { Kom- } \\
\text { ponen }\end{array}$} & \multirow[b]{2}{*}{$\begin{array}{l}\text { Peneri- } \\
\text { maan }\end{array}$} & \multicolumn{2}{|c|}{$\begin{array}{l}\text { Biaya Faktor } \\
\text { produksi }\end{array}$} & \multirow[b]{2}{*}{$\begin{array}{c}\text { Ketera- } \\
\text { ngan }\end{array}$} \\
\hline & & $\begin{array}{l}\text { Trada- } \\
\text { ble }\end{array}$ & $\begin{array}{l}\text { Non- } \\
\text { trada- } \\
\text { ble }\end{array}$ & \\
\hline $\begin{array}{l}\text { Harga } \\
\text { privat }\end{array}$ & A & B & $\mathrm{C}$ & $\mathrm{D}$ \\
\hline $\begin{array}{l}\text { Harga } \\
\text { sosial }\end{array}$ & $\mathrm{E}$ & $\mathrm{F}$ & $\mathrm{G}$ & $\mathrm{H}$ \\
\hline $\begin{array}{l}\text { Diver- } \\
\text { gensi }\end{array}$ & $\mathrm{I}=\mathrm{A}-\mathrm{E}$ & $\begin{array}{c}\mathrm{J}=\mathrm{B}- \\
\mathrm{F}\end{array}$ & $\begin{array}{l}\mathrm{K}=\mathrm{C} \\
-\mathrm{G}\end{array}$ & $\begin{array}{c}\mathrm{L}=\mathrm{D}- \\
\mathrm{H}\end{array}$ \\
\hline
\end{tabular}

Perhitungan PAM baris pertama adalah perhitungan harga privat atau harga pasar, yaitu harga yang benar-benar diterima dan dibayarkan oleh perusahaan. Perhitungan PAM baris kedua merupakan perhitungan berdasarkan harga sosial, yaitu harga output maupun input tradable pada tingkat perdagangan besar (dari lokasi petani) sama dengan harga internasional (border price).

Setelah seluruh kolom pada matriks terisi, maka dilakukan perhitungan analisis keunggulan kompetitif dan keunggulan komperatif usahatani manggis di Desa Babakan, Kecamatan Wanayasa.

a. Analisis Keunggulan Kompetitif

Analisis keunggulan kompetitif dilihat dari nilai PCR pada tabel PAM dengan rumus (Pearson dkk, 2005):

$$
\mathrm{PCR}=\frac{\mathrm{C}}{\mathrm{A}-\mathrm{B}}
$$

$\mathrm{C}$ : Biaya privat domestic factor

\section{A : Penerimaan private \\ B : Biaya privat tradable input}

Jika $\mathrm{PCR}<1$, artinya suatu komoditas akan memiliki keunggulan kompetitif atau memiliki daya saing yang tinggi di pasar internasional dan sebaliknya.

b. Analisis Keunggulan Komperatif

Analisis keunggulan komparatif dilihat nilai DRC pada tabel PAM dengan rumus (Pearson dkk, 2005):

$$
\mathrm{DRC}=\frac{\mathrm{G}}{\mathrm{E}-\mathrm{F}}
$$

$\mathrm{G}$ : Biaya sosial domestic factor

E : Penerimaan sosial

$\mathrm{C}$ : Biaya sosial tradable input

Jika $\mathrm{DRC}<1$, artinya suatu komoditas akan memiliki keunggulan komparatif dan dianggap lebih efesien 
dalam penggunaan sumberdaya dan sebaliknya.

Manggis merupakan tanaman tahunan (perennial crops) yang menghasilkan dan membutuhkan biaya dalam rentang waktu yang panjang, sehingga memerlukan tabel PAM untuk setiap periode selama umur ekonomis tanaman manggis yaitu 25 tahun. Rumus yang digunakan menurut Person dkk (2005) adalah:

$$
\mathrm{NPV}_{\mathrm{R}}=\sum_{t-1}^{n} \frac{R t}{(1+i) t}
$$

$\mathrm{R}$ : Nilai tunai (pada tahun ke-0)

Rt : Nilai masa mendatang

i : Tingkat suku bunga

$\mathrm{t}$ : Jumlah periode

\section{Analisis Dampak Kebijakan Pemerintah}

a. Kebijakan Input

- Input Transfer (IT)

$$
\mathrm{IT}=\mathrm{J}=\mathrm{B}-\mathrm{F}
$$

Jika nilai IT $>0$, kebijakan pemerintah menyebabkan keuntungan yang diterima lebih besar dibandingkan tanpa adanya kebijakan. IT $<0$ kebijakan pemerintah mengakibatkan keuntungan yang diterima secara finansial lebih kecil dibandingkan tanpa adanya kebijakan (Pearson dkk, 2005).

- Transfer Factor (FT)

$$
\mathrm{FT}=\mathrm{K}=\mathrm{C}-\mathrm{G}
$$

Nilai FT $>0$ maka terdapat subsidi negatif (pajak) pada input non tradable, sedangkan jika $\mathrm{FT}<0$ maka terdapat subsidi positif pada input non tradable (Pearson dkk, 2015).

- Nominal Protection Coeffecient on Input (NPCI).

$$
\begin{aligned}
& \text { NPCI } \quad= \\
& \frac{\text { Biaya Input Tradable Privat }}{\text { Biaya Input Tradable Sosial }}
\end{aligned}
$$

Jika NPCI > 1, adanya proteksi terhadap produsen input, sementara sektor yang menggunakan input tersebut akan dirugikan dengan tingginya biaya produksi. NPCI $<1$ menunjukkan adanya hambatan impor input, sehingga produksi menggunakan input lokal (Pearson dkk, 2015).

b. Kebijakan Output

- Transfer Output (OT)

$$
\mathrm{OT}=\mathrm{I}=\mathrm{A}-\mathrm{E}
$$

OT $>1$, masyarakat harus membeli output dengan harga yang lebih mahal dari harga yang seharusnya dibayarkan dan produsen menerima harga yang lebih tinggi dari harga yang seharusnya diterima dan sebaliknya (Pearson dkk, 2005).

- Nominal Protection Coeffecient on Output (NPCO)

$$
\mathrm{NPCO}=\frac{\mathrm{A}}{\mathrm{E}}
$$

Jika NPCO $<1$ maka kebijakan pemerintah menghambat peningkatan 
produksi. NPCO $>1$ maka dampak kebijakan pemerintah mendorong peningkatan produksi (Pearson dkk, 2005)

c. Kebijakan Input-Output

- Effective Protection Coeffecient (EPC)

$$
\mathrm{EPC}=\frac{\mathrm{A}-\mathrm{B}}{\mathrm{E}-\mathrm{F}}
$$

EPC $>1$, memberikan perlindungan berupa insentif dalam pengembangan produksi manggis dan sebaliknya (Pearson dkk, 2005).

\section{- Net Transfer (NT)}

$$
\mathrm{NT}=\mathrm{L}=\mathrm{D}-\mathrm{H}
$$

NT $>0$, menunjukkan tambahan surplus produsen atau menguntungkan petani manggis yang disebabkan oleh kebijakan pemerintah yang diterapkan pada input dan output, demikian juga sebaliknya (Pearson dkk, 2015).

- Profitablity Coefficient (PC)

$$
\begin{gathered}
\mathrm{PC}=\frac{\mathrm{D}}{\mathrm{H}} \\
\mathrm{PC}>0, \quad \text { dampak kebijakan }
\end{gathered}
$$
pemerintah menguntungkan petani manggis, demikian juga sebaliknya (Pearson dkk, 2005).

- Subsidy Ratio to Producer (SRP)

$$
\mathrm{SRP}=\frac{\mathrm{L}}{\mathrm{H}}
$$

SRP $>0$, kebijakan pemerintah memberikan dampak yang menguntungkan bagi petani manggis, demikian juga sebaliknya (Pearson dkk, 2005).

\section{HASIL DAN PEMBAHASAN}

Tanaman manggis merupakan tanaman yang diusahakan oleh petani di Desa Babakan dengan sistem tumpang sari. Luas lahan produksi manggis di Kecamatan Wanayasa adalah 6,19 ha dan produksi rata-rata tanaman manggis di Kecamatan Wanayasa adalah 3,43 ton (Dinas Pertanian, Perkebunan dan Kehutanan Kabupaten Purwakarta, 2015). Hasil buah manggis hanya 20 persen dari total produksi manggis yang memenuhi pasar ekspor dan 80 persen hasil produksi dijual di pasar lokal.

Petani manggis di Desa Babakan tidak menjadikan manggis sebagai usahatani utama karena manggis merupakan tanaman musiman dan tidak berbuah sepanjang tahun. Petani mengusahakan tanaman manggis dengan tanaman cengkeh, teh dan pala sebagai tanaman tumpang sari. Usia rata-rata responden adalah 46-55 tahun. Tingkat pendidikan petani responden rata-rata adalah SMA. Tingkat pengalaman usahatani rata-rata adalah $\geq 20$ tahun. Luas lahan lahan responden rata-rata adalah < 0,5 ha. Kepemilikan pohon manggis ratarata diatas 50-100 pohon dengan jarak tanaman yang digunakan adalah 10x10 m. Sebagian besar responden sudah memiliki 
pohon yang berbuah optimal yaitu di atas 20 tahun.

Bibit yang digunakan oleh petani responden didapatkan dari hasil pembibitan dari buah manggis yang dilakukan oleh petani sendiri. Petani menggunakan pupuk organik seperti pupuk kandang, jerami dan limbah rumah tangga. Manggis sudah dapat dipanen ketika berumur 8 tahun dan dipetik setelah berumur 104-108 hari sejak berbunga.

Penggunaan input dan output usahatani manggis di Desa Babakan, Kecamatan Wanayasa disajikan pada Tabel 6 (lampiran).

a. Harga Bibit Manggis

Harga sosial bibit manggis sama dengan harga privat karena bibit mangis diperoleh dari daerah tempat penelitian yaitu Rp 15.000/pohon.

b. Tingkat Suku Bunga

Tingkat suku bunga nominal (nominal interest rate) adalah 17,50\%, nilai ini diperoleh dari infomasi tingkat bunga kredit nominal tahun 2016. Tingkat suku bunga sosial (social interest rate) untuk modal kerja yaitu $18,02 \%$ per tahun dan modal investasi yaitu $13,02 \%$. Laju inflasi nasional pada tahun 2016 adalah 3,02\% (Bank Indonesia, 2016).

\section{c. Nilai Tukar Mata Uang}

Nilai tukar resmi adalah rata-rata nilai tukar (Rp/US\$) 2016 yaitu Rp 13.307,00/US\$. Penggunaan nilai tukar Rupiah terhadap US\$ dikarenakan US\$ merupakan mata uang yang digunakan di pasar internasional.

d. Harga Pupuk

Harga pupuk kandang adalah $\mathrm{Rp}$ 10.000/karung (50 kg). Harga sosial pupuk kandang sama dengan harga privat, karena pupuk kandang diperoleh dari daerah sekitar tempat penelitian.

e. Harga obat-obatan

Harga gandasil daun adalah $\mathrm{Rp}$ 15.000/bungkus. Harga sosial gandasil sama dengan harga privat, karena berasal dari produk lokal.

f. Harga Peralatan

Harga privat peralatan sama dengan harga sosial peralatan yaitu harga yang diperoleh petani pada saat membeli peralatan.

\section{g. Tenaga Kerja}

Harga privat tenaga kerja sama dengan harga sosial yaitu upah kegiatan budidaya rata-rata yang berlaku di tempat penelitian adalah Rp 50.000/HOK untuk tenaga kerja laki-laki dan Rp 25.000/HOK untuk tenaga kerja perempuan, sedangkan upah tenaga kerja pemanenan adalah $\mathrm{Rp}$ $1.000 / \mathrm{Kg}$. 
h. Harga Sewa Lahan

Kepemilikan lahan petani responden adalah milik sendiri, namun dalam analisis usahatani nilai lahan tetap diperhitungkan. Sewa lahan di lokasi penelitian rata-rata $\mathrm{Rp}$ $2.000 .000 /$ tahun/ha.

\section{i. Harga Output}

Harga privat manggis adalah $\mathrm{Rp}$ 10.000/Kg. Harga Sosial manggis menggunakan harga Free on Board (FOB) yaitu $\mathrm{Rp} 43.200,66 / \mathrm{Kg}$.

j. modal kerja

Modal kerja merupakan biaya yang dikeluarkan petani untuk membiayai proses produksi dalam kurun waktu satu tahun (Pearson dkk, 2005). Modal kerja privat adalah $17,50 \%$ dan modal kerja sosial adalah $18,02 \%$.

Tabel 2. Perhitungan Harga Sosial Manggis

\begin{tabular}{|c|c|c|}
\hline No. & Uraian & Nilai \\
\hline 1 & Free on Board $(\mathrm{US} \$ / \mathrm{Kg})^{1}$ & 3,37 \\
\hline 2 & Exchange Rate (Rate/US\$) & $13.412,66$ \\
\hline 3 & $\begin{array}{l}\text { Free on Board Indonesia } \\
(\mathrm{Rp} / \mathrm{Kg})^{1}\end{array}$ & $45.200,66$ \\
\hline 4 & Transportasi $(\mathrm{Rp} / \mathrm{Kg})^{2}$ & $1.000,00$ \\
\hline 5 & $\begin{array}{l}\text { Nilai Sebelum Diproses } \\
(\mathrm{Rp} / \mathrm{Kg})\end{array}$ & $44.200,66$ \\
\hline 6 & $\begin{array}{l}\text { Faktor Konversi Ketika } \\
\text { Diproses }(\%)^{1}\end{array}$ & 1.00 \\
\hline 7 & $\begin{array}{l}\text { Harga Paritas Ekspor di } \\
\text { Tingkat Pedagang Besar } \\
(\mathrm{Rp} / \mathrm{Kg})\end{array}$ & $44.200,66$ \\
\hline 8 & $\begin{array}{l}\text { Biaya Distribusi ke Tingkat } \\
\text { Petani }(\mathrm{Rp} / \mathrm{Kg})^{2}\end{array}$ & $1.000,00$ \\
\hline 9 & $\begin{array}{l}\text { Harga Sosial di Tingkat } \\
\text { Petani }(\mathrm{Rp} / \mathrm{Kg})^{3}\end{array}$ & $43.200,66$ \\
\hline
\end{tabular}

Berdasarkan perhitungan analisis daya saing pada Tabel 3, diketahui bahwa usahatani manggis di Desa Babakan memiliki penerimaan privat sebesar $\mathrm{Rp}$ 33.096.949,41 dan memiliki penerimaan sosial sebesar Rp 132.953.278,41.

Usahatani manggis di Desa Babakan memiliki keuntungan privat sebesar $\mathrm{Rp}$ 2.228.948,71/Rp/Ha dan keuntungan sosial sebesar Rp 103.199.265,31/Rp/Ha. Perbedaan antara keuntungan finansial dengan keuntungan ekonomi adalah adanya divergensi, yaitu terdapat perbedaan pada harga privat dan sosial, dimana harga privat lebih rendah daripada harga sosial (Hermayanti, 2013).

Tabel 3. Policy Analysis Matrix (PAM) usahatani manggis di Desa Babakan, 2017

\begin{tabular}{|c|c|c|c|c|}
\hline \multirow[b]{2}{*}{ Indikator } & \multirow{2}{*}{$\begin{array}{c}\text { Penerimaan } \\
\text { (Output) }\end{array}$} & \multicolumn{2}{|c|}{ Biaya } & \multirow[b]{2}{*}{ Keuntungan } \\
\hline & & $\begin{array}{c}\text { Input } \\
\text { Tradable }\end{array}$ & $\begin{array}{c}\text { Input } \\
\text { Non Tradble }\end{array}$ & \\
\hline Privat & $33.096 .949,41$ & $4.346 .639,82$ & $26.521 .360,89$ & $2.228 .948,71$ \\
\hline Sosial| & $132.953 .278,41$ & $4.233 .570,16$ & $25.520 .442,95$ & $103.199 .265,31$ \\
\hline Divergensi & $(99.856 .329,00)$ & $113.069,66$ & $1.000 .917,94$ & $(100.970 .316,60)$ \\
\hline
\end{tabular}

Analisis komponen indikator daya saing usahatani manggis di Desa Babakan disajikan pada Tabel 4.

Tabel 4. Komponen Indikator Daya Saing Usahatani Manggis di Desa Babakan

\begin{tabular}{lll}
\hline No & Indikator & Nilai \\
\hline 1 & PCR & 0,92 \\
2 & DRCR & 0,20 \\
\hline
\end{tabular}

Nilai PCR usahatani manggis di lokasi penelitian adalah 0,92 . Hal ini menunjukkan bahwa untuk mendapatkan nilai tambah output sebesar satu satuan pada harga privat, dibutuhkan faktor domestik sebesar 92\%. Nilai DRCR 
usahatani manggis di lokasi penelitian adalah 0,20. Hal ini menunjukkan bahwa untuk mendapatkan nilai tambah output sebesar satu satuan pada harga privat, dibutuhkan faktor domestik sebesar 20\%.

Nilai PCR dan DRCR $<1$ menunjukkan bahawa usahatani manggis di Desa Babakan memiliki keunggulan kompetitif dan komparatif sehingga layak untuk dikembangkan.

Andala dkk (2014) dalam penelitiannya yang berjudul keunggulan kompetitif dan komparatif usahatani manggis di Kabupaten Tanggamus menyimpulkan bahwa usahatani manggis memiliki keunggulan kompetitif dan komparatif dengan nilai PCR 0,349 dan DRCR 0,506. Hal ini menunjukkan bahwa berdasarkan harga privat usahatani manggis di Kabupaten Tunggamus lebih efisien dibandingkan usahatani yang dilakukan di Desa Babakan. Namun, berdasarkan harga sosial, usahatani manggis di Desa Babakan lebih rendah dari biaya usahatani manggis di Kabupaten Tunggamus.

\section{Analisis Dampak Kebijakan}

Nilai nominal protection coeffecient input (NPCI) dan input transfer (IT) dari hasil analisis matriks kebijakan PAM menunjukkan bahwa nilai NPCI usaha manggis lebih besar dari 1, artinya kebijakan pemerintah terhadap input tradable usahatani manggis di Desa Babakan menyebabkan petani memperoleh keutungan. Hasil tersebut diperkuat dengan nilai IT yang positif. Hasil analisis kebijakan pemerintah dapat dilihat pada Tabel 5.

Tabel 5. Hasil Analisis Kebijakan Pemerintah

\begin{tabular}{llr}
\hline No & Indikator & \multicolumn{1}{c}{ Nilai } \\
\hline 1 & IT (Rp) & $113.069,66$ \\
2 & FT (Rp) & $1.000 .917,94$ \\
3 & NPCI & 1,03 \\
4 & OT (Rp) & $-99.856 .320,00$ \\
5 & NPCO & 0,25 \\
6 & NT (Rp) & $-100.970 .316,60$ \\
7 & PC & 0,02 \\
8 & EPC & 0,22 \\
9 & SRP & $-0,98$ \\
\hline
\end{tabular}

a. Dampak Kebijakan terhadap Harga Manggis

Dari hasil analisis menunjukkan $\mathrm{NPCO}<1$, artinya harga manggis yang diterima petani lebih rendah dari seharusnya. Hal ini menunjukkan belum efektifnya kebijakan pemerintah dalam memproteksi petani. Nilai OT adalah negatif, artinya konsumen dalam negeri membeli manggis dengan harga yang lebih rendah daripada harga sebenarnya, sehingga petani tidak memperoleh tambahan penerimaan dan petani mendapat kerugian dari sisi output dengan nilai OT yang negatif. 
b. Dampak Kebijakan terhadap Pendapatan Usaha Manggis

Nilai NT yang negatif menunjukkan keutungan harga privat lebih rendah dibandingkan dengan keuntungan yang dinilai atas harga sosial. Hal ini mengakibatkan kerugian terhadap petani karena adanya pengurangan surplus produsen sebagai akibat dari kebijakan pemerintah terhadap input output.

Nilai EPC yang diperoleh adalah kecil dari satu $(<1)$, artinya rendahnya perlindungan dan kebijakan pemerintah terhadap usahatani manggis di Desa Babakan. Hal ini menyebabkan kebijakan yang ada kurang mampu meningkatkan tambahan keuntungan terhadap usahatani manggis, sehingga petani hanya menerima sekitar 22 persen dari nilai harga sosial yang sebenarnya.

Hasil PC juga menunjukkan petani manggis hanya menerima 2 persen dari keuntungan nilai harga sosial yang sebenarnya, artinya adanya kebijakan pemerintah menyebabkan keuntungan yang diterima produsen lebih rendah daripada tanpa adanya kebijakan.

Nilai SRP menunjukkan nilai negatif, artinya kebijakan pemerintah yang berlaku selama ini menyebabkan produsen mengeluarkan biaya produksi lebih tinggi sebesar 98 persen dibanding opportunity cost-nya.

\section{KESIMPULAN DAN SARAN}

Kesimpulan

Usahatani manggis di Desa Babakan memiliki nilai $\mathrm{PCR}<1$, artinya secara finansial usahatani manggis memiliki keunggulan kompetitif dengan keutungan finansial yang dihasilkan adalah $\mathrm{Rp}$ 2.228.948,71 per hektar. Sedangkan secara ekonomi, usahatani manggis memiliki keunggulan komparatif karena nilai $\mathrm{DRCR}<1$ dengan keuntungan ekonomi yang dihasilkan adalah $\mathrm{Rp}$ 103.199.265,31 per hektar, artinya usahatani manggis di Desa Babakan layak diteruskan karena memiliki keuntungan baik secara finansial maupun secara ekonomi.

Nilai PCR dan DRCR tersebut mengindikasikan meskipun tanpa ada bantuan dan intervensi pemerintah, usahatani manggis di Desa Babakan dapat berdaya saing dan bertahan di pasar persaingan sempurna (pasar internasional). Namun nilai PCR yang mendekati satu akan mudah kehilangan keunggulan kompetitifnya apabila terjadi perubahan terhadap biaya input maupun harga output. 
Dampak kebijakan pemerintah terhadap usahatani manggis di Desa Babakan belum berjalan efektif atau sampai saat ini kebijakan input-output kurang menguntungkan bagi petani manggis di Desa Babakan. Hal tersebut ditunjukkan oleh nilai EPC $<1$ yaitu 0,22 per hektar.

\section{Saran}

Berdasarkan nilai PCR yang mendekati 1, sehingga sangat berisiko untuk manggis kehilangan efisiensinya secara finansial (tidak memiliki keunggulan kompetitif), maka pemerintah perlu menambah dan memberikan subsidi terhadap input domestik, melakukan penyuluhan dan pelatihan kepada petani sehingga produktifitas tenaga kerja meningkat, serta pemerintah dapat menghapus PPN terhadap produk pendukung pertanian, maka manggis akan lebih berdaya saing dan produsen akan mendapat keuntungan yang lebih besar. Pemerintah diharapkan membuat kebijakan dan perhatian khusus untuk komoditas ekspor terutama manggis yang merupakan penyumbang devisa terbesar negara atau eskpor tertinggi dalam komoditas buah

\section{DAFTAR PUSTAKA}

Andala, A., Abidin, Z., \& Situmorang, S. (2014). Keunggulan Kompetitif dan
Komparatif Usahatani Manggis di Kabupaten Tanggamus.

Badan Pusat Statitik Jawa Barat. (2015). Produksi Hortikultura Buah dan Sayuran Tahunan Jawa Barat. Dipetik Agustus 12, 2017, dari https://jabar.bps.go.id/new/website/ pdf publikasi/Produksi-

Hortikultura-Buah-dan-Sayur-

Tahunan-Jawa-Barat-2015.pdf

BPS Kabupaten Purwakarta. (2015). Kecematan Wanayasa Dalam Angka 2015. Dipetik Agustus 12, 2017, dari https://purwakartakab.bps.go.id/ne w/website/pdf_publikasi/Kecamata n-Wanayasa-Dalam-Angka2015.pdf

BPS Kabupaten Purwakarta. (2016). Kecematan Wanayasa Dalam Angka 2016. Dipetik Agustus 12, 2017, dari file://C:/Users/acer/Downloads/Ke camatan-Wanayasa-Dalam-Angka2016--\%20(10).pdf

Kementerian Pertanian. (2015). Statistik Pertanian. Dipetik Agustus 12, 2017 ,

darihttp://epublikasi.setjen.pertania n.go.id/epublikasi/StatistikPertania $\mathrm{n} / 2015 /$ Statistik $\% 20$ Pertanian $\% 202$ 015/files/assets/common/download s/Statistik\%20Pertanian\%202015.p $\underline{\mathrm{df}}$

Kementerian Riset, Teknologi dan Pendidikan Tinggi. (2015). Undang-Undang Republik Indonesia Nomor 13 Tahun 2010 Tentang Hortikultura. Diambil kembali dari http://www.spi.or.id/wpcontent/uploads/2015/01/Undang _ Undang_No_13_2010_hortikultura. pdf

Keuangan, K. (t.thn.). Outlook Ekonomi. Dipetik 9 28, 2017, dari https://www.kemenkeu.go.id/Berita 
/outlook-ekonomi-2017-hati-hatibukan-berarti-tidak-optimistis-0

Kholilah. (2017). Analisis Daya Saing Usahatani Manggis Sebagai Komoditas Ekspor (Studi Kasus di Kelompok Tani Saripuspa, Desa Puspahiang, Kecamatan Puspahiang, Kabupaten Tasikmalaya, Jawa barat). Skripsi. Jatinangor: Universitas Padjadjaran

Kuma'at. (1992). Sistem Pemasaran Sayuran Dataran Tinggi di Provinsi Sulawesi Utara. Thesis MS - FPS. Bogor: Institut Pertanian Bogor.

Kustiari, R., Purba, H. J., \& Hermanto. (2011). Daya Saing Manggis Indonesia di Pasar Dunia (Studia Kasus di Sumatera Barat). Bogor: Pusat Sosial Ekonomi dan Kebijakan Pertanian, Institut Pertanian Bogor.

Monke and Pearson. (1989). The Policy Analysis Matrix for Agricultural Development. New York: Cornel University Press.

Muslim , C., \& Nurasa, T. (2011). Daya Saing Komoditas Promosi Ekspor Manggis, Sistem Pemasaran dan Kemantapannya di Dalam Negeri (Studi Kasus di Kabupaten Purwakarta, Jawa Barat). Bogor:
Pusat Sosial Ekonomi dan Kebijakan Pertanian.

\section{UNCOMTRADE}

(2015).UNCOMTRADE Statistic Database 2015. Dipetik September 1, 2017, dari https://comtrade.un.org

United Nation Commodity Trade

[UNCOMTRADE].

(2013).

UNCOMTRADE

Statistics

Database 2013. Dipetik September 1, 2017, dari www.un.uncomtrade.org

United Nation Commodity Trade Statistic. (2015). Database 2015. Dipetik September 1, 2017, dari Data Query of Import and Export: http://comtrade.un.org

United Nation Conference on Trade and Development . (2015). Economic Trends. Exchange Rates crossrates, annual, 2010-2014. Dipetik September 1, 2017, dari http://unctadstat.unctad.org 
Tabel 6. Harga Privat dan Harga Sosial Manggis di Kelompok Tani Wanayasa, Desa Babakan, Kecamatan Wanayasa, Kabupaten Purwakarta

\begin{tabular}{|c|c|c|c|c|}
\hline \multirow{2}{*}{ Kategori } & \multirow{2}{*}{ Uraian } & \multirow{2}{*}{ Satuan } & \multicolumn{2}{|c|}{ Harga } \\
\hline & & & Privat & Sosial \\
\hline \multirow{3}{*}{ Input Tradable } & Bibit & Rp/Pohon & $15.000,00$ & $15.000,00$ \\
\hline & Pupuk Kandang & Rp/Karung & $10.000,00$ & $10.000,00$ \\
\hline & Gandasil B \& D & Rp/Bungkus & $15.000,00$ & $15.000,00$ \\
\hline \multirow{23}{*}{$\begin{array}{c}\text { Faktor } \\
\text { Domestik }\end{array}$} & Peralatan & & & \\
\hline & a. Cangkul & $\mathrm{Rp} /$ Unit & $14.396,54$ & $12.680,13$ \\
\hline & b. Sabit & $\mathrm{Rp} /$ Unit & $10.077,58$ & $8.876,09$ \\
\hline & c. Garpu & $\mathrm{Rp} /$ Unit & $26.776,97$ & $22.376,65$ \\
\hline & d. Timbangan & $\mathrm{Rp} /$ Unit & $28.643,78$ & $22.988,24$ \\
\hline & e. Galah & $\mathrm{Rp} /$ Unit & $4.318,96$ & $3.804,04$ \\
\hline & f. Kantong kain & $\mathrm{Rp} /$ Unit & $4.318,96$ & $3.804,04$ \\
\hline & g. Karung & $\mathrm{Rp} /$ Unit & 809,77 & 729,84 \\
\hline & h. Kerangjang & $\mathrm{Rp} /$ Unit & $57.586,16$ & $50.720,53$ \\
\hline & i. Semprotan & $\mathrm{Rp} /$ Unit & $85.931,33$ & $68.964,71$ \\
\hline & Tenaga Kerja & & & \\
\hline & a. Persiapan lahan & $\mathrm{Rp} / \mathrm{HOK}$ & $50.000,00$ & $50.000,00$ \\
\hline & b. Penanaman & $\mathrm{Rp} / \mathrm{HOK}$ & $50.000,00$ & $50.000,00$ \\
\hline & c. Pemupukan & $\mathrm{Rp} / \mathrm{HOK}$ & $50.000,00$ & $50.000,00$ \\
\hline & d. Penyiangan & $\mathrm{Rp} / \mathrm{HOK}$ & $25.000,00$ & $25.000,00$ \\
\hline & e. Pemanenan & $\mathrm{Rp} / \mathrm{Kg}$ & $1.000,00$ & $1.000,00$ \\
\hline & f. Pengiriman & $\mathrm{Rp} / \mathrm{Kg}$ & $1.000,00$ & $1.000,00$ \\
\hline & PBB & $\mathrm{Rp} / \mathrm{Ha}$ & 528.500 & 528.500 \\
\hline & Modal & & & \\
\hline & a. Modal kerja & $\%$ / Tahun & $17,50 \%$ & $18,02 \%$ \\
\hline & b. Modal Investasi & $\%$ / Tahun & $17,50 \%$ & $13,02 \%$ \\
\hline & Sewa Lahan & $\mathrm{Rp} /$ Tahun & $2.000 .000,00$ & $2.000 .000,00$ \\
\hline & Nilai Tukar & Rp/US\$ & $13.307,00$ & $13.412,66$ \\
\hline Output & Produksi & $\mathrm{Rp} / \mathrm{Kg}$ & $10.000,00$ & $43.200,66$ \\
\hline
\end{tabular}

